\title{
An assessment of the trace element status of grazing livestock in the Wendon Valley
}

\author{
N.D. GRACE ${ }^{1}$, G.R. SINCLAIR ${ }^{2}$, M. CRAIGHEAD ${ }^{3}$ and B. WATT ${ }^{3}$ \\ ${ }^{1}$ AgResearch, Grasslands, Private Bag 11008, Palmerston North \\ ${ }^{2}$ Gore Veterinary Supplies, PO Box 242, Gore \\ ${ }^{3}$ Ravensdown Fertiliser Co-op Ltd, PO Box 1049, Christchurch \\ ${ }^{1}$ gracen@agresearch.cri.nz
}

\begin{abstract}
The Co (Vitamin $\mathrm{B}_{12}$, $\mathrm{Se}, \mathrm{Cu}$ and $\mathrm{I}$ status of livestock on 12 Wendon Valley farms was determined from the trace element concentrations of pasture, blood and liver samples collected in spring and autumn and comparing them to accepted trace element reference ranges established from earlier New Zealand-wide trace element supplementation trials recording animal responses. Both marginal $\mathrm{Co}$ and $\mathrm{Se}$ deficiencies in lambs were found on two farms while another three farms were marginally Co deficient, one farm was very Co deficient and a further two farms were marginally Se deficient. Iodine deficiency was observed in new-born lambs from ewes wintered on swedes, whereas the $\mathrm{Cu}$ status of all sheep was adequate. No Co deficiency was found in cattle but Se deficiency was observed on four farms. A marked depletion of liver $\mathrm{Cu}$ stores and $\mathrm{Cu}$ deficiency was found in all cattle and deer during the late winter/ early spring. Growth responses to Vitamin $\mathrm{B}_{12}$ and Se supplementation in lambs, and the absence of goitre in new-born lambs to I supplementation in ewes were also observed. The established diagnostic protocols based on pasture, blood and liver samples were shown to be effective in determining the trace element status of grazing livestock in the Wendon Valley.
\end{abstract}

Keywords: blood, cattle, copper, deer, iodine, liver, pasture, selenium, sheep, vitamin $\mathrm{B}_{12}$

\section{Introduction}

Trace element deficiencies have been well documented in New Zealand (Andrews et al. 1963; Cunningham 1950; Sinclair \& Andrew1958). Marginal Co, Se, Cu and I deficiencies result in poor animal performance and a decrease in farm profitability (Grace 1994). While biochemical criteria or tissue reference ranges to assess the trace element status of grazing livestock have been established from trace element supplementation trials animal recording performance responses (Clark et al.
1985, 1998; Metherell et al. 1997) the use and value of this information is not always appreciated. Once a particular trace element deficiency has been diagnosed, then an effective strategy can be implemented to prevent the problem (Grace 1992). In situations where farmers do not know the trace element status of their livestock, then there are costs in terms of lost production if they do not supplement deficient animals and if they supplement adequate animals then this is also an unnecessary cost. Further, the assessment of the trace element status of livestock should be conducted as part of the overall farm animal health programme. The Wendon Valley study was set up to demonstrate the protocols and procedures used to determine the trace element status of livestock.

\section{Materials and methods}

\section{Farms}

Twelve farms in the Wendon Valley, near Gore, selected on the basis of farmer interest and commitment, were used for the trace element study. The properties varied in size from 1500 to 11000 stock units consisting of sheep, cattle and some deer. The farms were made up of river flats and terraces (Recent soils) (Hewitt 1992), rolling downs and hills (Pallic and Brown soils) with larger properties having steeper hill country (Brown soils). On most properties brassica crops were used as a winter feed supplement.

\section{Collection of herbage and animal monitoring}

Pasture and brassicas. In the first year in December 1997, and in February and June 1998, three to five sites on each farm were selected depending on soil type, fertiliser history and topography for sampling pasture on a $100 \mathrm{~m}$ transect. Likewise kale and swede crops were randomly sampled in June 1998. All herbage samples were analysed for $\mathrm{Co}, \mathrm{Se}, \mathrm{Cu}$ and I.

Monitor Animals. Small paddocks from each farm which had not been topdressed in the last 5-10 years with trace element-amended fertilisers were grazed with 10 weaned lambs from December 1997 to May 1998 and with 10 weaner calves and hinds from March 1998 to 
October 1998. These monitor animals and their dams had not been supplemented with trace elements in the previous $8-10$ months.

The lambs were bled in December and then again in May when their livers were also collected at slaughter. Calves and weaner hinds were bled in April and then in October when liver biopsies were taken. All blood (serum) and liver samples were analysed for Vitamin $\mathrm{B}_{12}$, Se and $\mathrm{Cu}$.

\section{Trace element supplementation trials}

On the basis of the pasture and animal tissue data collected in the first year (1997/1998), farms were selected for $\mathrm{Co}$, Se and I supplementation studies in $1998 / 1999$ to demonstrate the effect of trace element deficiencies on animal performance.

Cobalt supplementation. From 200-300 weaned lambs, on each of six farms (numbers 1, 2, 4, 7, 9 and 11), 60 animals were selected, eartagged and divided into two groups of 30 in December 1998. Group 1 lambs were the untreated control and Group 2 were injected with $6 \mathrm{mg}$ Vitamin B 12 (SMARTShot B 12 , AgResearch). They were all weighed and 10 monitor animals/group bled at the start of the trial in December. All lambs were grazed as a single group and weighed at about monthly intervals for the next 6 months. Blood samples were collected in March and May together with liver samples at slaughter in May 1999.

Selenium supplementation. From 200-300 weaned lambs, on each of five farms (numbers 1, 3, 4, 5 and 6) in December 1998, 60 lambs were selected, eartagged and divided into two groups of 30 . Group 1 lambs were the untreated control and Group 2 were injected with 50 $\mathrm{mg} \mathrm{Se}$ as $\mathrm{BaSeO}_{4}$ (Deposel, Novartis). They were grazed as a single group, weighed at the start of the trial and at about monthly intervals for 6 months, with blood being collected from 10 monitor animals/group in December, March and May 1999 when livers were collected at slaughter.

Iodine supplementation. On two farms (numbers 3 and 5) in early March 1999, 800 ewes were eartagged and divided into two groups of 400. Group 1 ewes were the control while Group 2 were injected with $1.5 \mathrm{ml}(390 \mathrm{mg}$ I) of iodised oil (Flexidine, Bomac). They were grazed as a single group, joined with the ram in late April, scanned in late July and separated into the two treatment groups for lambing in mid September 1999. The ewes on farm 3 were wintered on pasture while the ewes on farm 5 were fed swedes 8 weeks before lambing. All

Table 1 The pasture Co, Se, Cu and I mean concentrations (mg/kgDM) from Wendon Valley Farms in 1997 and 1998. Data presented are from transects with lowest pasture concentrations at each sampling. A range is given for the February 1998 sampling. Bold figures indicate deficiencies.

\begin{tabular}{|c|c|c|c|c|c|c|c|c|c|c|c|c|}
\hline \multirow[b]{2}{*}{ Farm } & \multicolumn{3}{|c|}{----------- Co ---------- } & \multicolumn{3}{|c|}{---------- Se ---------- } & \multicolumn{3}{|c|}{----------- Cu ------------ } & \multicolumn{3}{|c|}{------------ I ------------ } \\
\hline & Dec & Feb & Jul & Dec & Feb & Jul & Dec & Feb & Jul & Dec & Feb & Jul \\
\hline 1 & 0.15 & $\begin{array}{c}\mathbf{0 . 0 7} \\
0.07-0.09\end{array}$ & 0.11 & 0.03 & $\begin{array}{c}0.04 \\
0.04-0.08\end{array}$ & 0.5 & 6 & $\begin{array}{c}8 \\
8-10\end{array}$ & 10 & 0.09 & $\begin{array}{c}\mathbf{0 . 1 1} \\
0.11-0.16\end{array}$ & 0.16 \\
\hline 2 & 0.14 & $\begin{array}{c}\mathbf{0 . 0 7} \\
0.07-0.12\end{array}$ & 0.1 & 0.02 & $\begin{array}{c}0.03 \\
0.03-0.05\end{array}$ & 0.04 & 6 & $\begin{array}{c}11 \\
11-12\end{array}$ & 10 & 0.12 & $\begin{array}{c}\mathbf{0 . 1 3} \\
0.13-0.32\end{array}$ & 0.16 \\
\hline 3 & 0.11 & $\begin{array}{c}0.14 \\
0.14-0.17\end{array}$ & 0.18 & 0.02 & $\begin{array}{c}0.03 \\
0.03-0.03\end{array}$ & 0.04 & 5 & $\begin{array}{c}12 \\
11-14\end{array}$ & 10 & 0.09 & $\begin{array}{c}\mathbf{0 . 0 5} \\
0.05-0.07\end{array}$ & 0.30 \\
\hline 4 & 0.10 & $\begin{array}{c}0.07 \\
0.07-0.07\end{array}$ & 0.18 & 0.03 & $\begin{array}{c}0.03 \\
0.03-0.12\end{array}$ & 0.06 & 7 & $\begin{array}{c}9 \\
9-13\end{array}$ & 11 & 0.19 & $\begin{array}{c}0.05 \\
0.05-0.08\end{array}$ & 0.72 \\
\hline 5 & 0.28 & $\begin{array}{c}0.11 \\
0.11-0.26\end{array}$ & 0.37 & 0.03 & $\begin{array}{c}0.04 \\
0.04-0.07\end{array}$ & 0.04 & 6 & $\begin{array}{c}11 \\
11-15\end{array}$ & 9 & 0.19 & $\begin{array}{c}\mathbf{0 . 0 5} \\
0.07-0.14\end{array}$ & 0.07 \\
\hline 6 & 0.09 & $\begin{array}{c}\mathbf{0 . 0 8} \\
0.08-0.11\end{array}$ & 0.43 & 0.04 & $\begin{array}{c}0.04 \\
0.04-0.06\end{array}$ & 0.05 & 8 & $\begin{array}{c}9 \\
9-12\end{array}$ & 12 & 0.14 & $\begin{array}{c}0.07 \\
0.09-0.22\end{array}$ & 0.3 \\
\hline 7 & 0.05 & $\begin{array}{c}\mathbf{0 . 0 5} \\
0.05-0.12\end{array}$ & 0.14 & 0.06 & $\begin{array}{c}0.05 \\
0.05-0.15\end{array}$ & 0.05 & 6 & $\begin{array}{c}8 \\
8-11\end{array}$ & 9 & 0.16 & $\begin{array}{c}0.09 \\
0.15-0.20\end{array}$ & 0.41 \\
\hline 8 & 0.08 & $\begin{array}{c}\mathbf{0 . 0 9} \\
0.09-0.22\end{array}$ & 0.17 & 0.03 & $\begin{array}{c}0.04 \\
0.04-0.13\end{array}$ & 0.08 & 6 & $\begin{array}{c}6 \\
6-12\end{array}$ & 12 & 0.16 & $\begin{array}{c}0.15 \\
0.15-0.20\end{array}$ & 0.80 \\
\hline 9 & 0.09 & $\begin{array}{c}\mathbf{0 . 0 9} \\
0.009-0.13\end{array}$ & 0.40 & 0.03 & $\begin{array}{c}0.05 \\
0.05-0.13\end{array}$ & 0.06 & 6 & $\begin{array}{c}11 \\
11-13\end{array}$ & 13 & 0.15 & $\begin{array}{c}0.13 \\
0.13-0.22\end{array}$ & 0.95 \\
\hline 10 & 0.13 & $\begin{array}{c}\mathbf{0 . 0 8} \\
0.08-0.21\end{array}$ & 0.11 & 0.02 & $\begin{array}{c}0.04 \\
0.04-0.11\end{array}$ & 0.8 & 8 & $\begin{array}{c}8 \\
8-10\end{array}$ & 9 & 0.20 & $\begin{array}{c}0.15 \\
0.15-0.68\end{array}$ & 0.24 \\
\hline 11 & 0.16 & $\begin{array}{c}0.14 \\
0.14-0.30\end{array}$ & 0.24 & 0.03 & $\begin{array}{c}0.05 \\
0.05-0.24\end{array}$ & 0.10 & 6 & $\begin{array}{c}7 \\
7-11\end{array}$ & 10 & 0.21 & $\begin{array}{c}0.22 \\
0.22-0.26\end{array}$ & 0.37 \\
\hline 12 & 0.14 & $\begin{array}{c}0.17 \\
0.17-0.19\end{array}$ & 0.23 & 0.04 & $\begin{array}{c}0.09 \\
0.09-0.12\end{array}$ & 0.07 & 6 & $\begin{array}{c}9 \\
9-10\end{array}$ & 12 & 0.51 & $\begin{array}{c}0.36 \\
0.36-0.57\end{array}$ & 0.4 \\
\hline Dietary & emen & ts $(\mathrm{mg} / \mathrm{kgDM}$ & vi) (G & & & & & & & & & \\
\hline $\begin{array}{l}\text { Sheep } \\
\text { Cattle }\end{array}$ & & $\begin{array}{l}0.1 \\
0.06\end{array}$ & & & $\begin{array}{l}0.03 \\
0.03\end{array}$ & & & $\begin{array}{r}5 \\
10\end{array}$ & & & $\begin{array}{l}0.15 \\
0.15\end{array}$ & \\
\hline
\end{tabular}


Table 2 Mean kale and swedes Co, Se, Cu and I concentrations (mg/kgDM) from Wendon Valley Farms in June 1998. Bold figures indicate deficiencies.

\begin{tabular}{|c|c|c|c|c|c|c|c|c|c|c|c|c|c|c|c|c|c|}
\hline \multirow{3}{*}{ Farm } & \multirow{2}{*}{\multicolumn{9}{|c|}{$\longrightarrow$ Swedes $\longrightarrow$}} & \multirow{2}{*}{\multicolumn{8}{|c|}{$\longrightarrow$ Kale }} \\
\hline & & & & & & & & & & & & & & & & & \\
\hline & Co & $\mathrm{Se}$ & $\mathrm{Cu}$ & 1 & Co & $\mathrm{Se}$ & $\mathrm{Cu}$ & I & & Co & $\mathrm{Se}$ & $\mathrm{Cu}$ & 1 & Co & $\mathrm{Se}$ & $\mathrm{Cu}$ & 1 \\
\hline 1 & 0.13 & 0.05 & 4 & 0.22 & 0.05 & 0.03 & 3 & $<0.05$ & & & & & & & & & \\
\hline 3 & 0.1 & 0.03 & 4 & 0.24 & 0.02 & 0.02 & 6 & $<0.05$ & & & & & & & & & \\
\hline 4 & 0.03 & 0.03 & 4 & 0.24 & 0.03 & 0.03 & 4.5 & $<0.05$ & & & & & & & & & \\
\hline 6 & 0.09 & 0.03 & 5 & 0.24 & 0.04 & 0.03 & 2.8 & $<0.05$ & & & & & & & & & \\
\hline 7 & & & & & & & & & & 0.04 & 0.06 & 2 & 0.07 & 0.05 & 0.02 & 3 & 0.17 \\
\hline 8 & 0.08 & 0.07 & 5 & 0.59 & 0.06 & 0.02 & 1.5 & $<0.05$ & & & & & & & & & \\
\hline 9 & 0.05 & 0.09 & 4 & 0.16 & 0.02 & 0.02 & 1.2 & $<0.05$ & & & & & & & & & \\
\hline 10 & & & & & & & & & & 0.11 & 0.06 & 2 & 0.1 & 0.07 & 0.05 & 4 & 0.19 \\
\hline 12 & & & & & & & & & & 0.04 & 0.06 & 4 & 0.05 & 0.02 & 0.03 & 2 & 0.12 \\
\hline Dietary & iremer & ts (mg & $/ \mathrm{kgD}$ & M) (Gr & & Co & $\mathrm{Se}$ & $\mathrm{Cu}$ & I & & & & & & & & \\
\hline Sheep & & & & & & 0.1 & 0.03 & 5 & 0.15 & & & & & & & & \\
\hline Cattle & & & & & & 0.06 & 0.03 & 10 & 0.15 & & & & & & & & \\
\hline
\end{tabular}

dead lambs were post mortemed and the numbers of lambs born dead or alive recorded. At docking, the lambing and neonatal mortality percents were calculated. At docking, blood and milk samples were collected from 10 monitor ewes per group for I determinations.

\section{Statistics}

Significant differences between treatments were determined by analysis of variance using Minitab (Minitab Corporation, PA, USA).

\section{Results}

There was considerable variation between transects within a farm (all data not shown), the time of sampling and between farms (Table 1). Cobalt-deficient pastures (i.e., $<0.1 \mathrm{mg} \mathrm{Co} / \mathrm{kgDM}$ ) were observed only on some farms in December and February but not in July. Likewise, Se-deficient pastures (i.e., <0.03 mg Se/ $\mathrm{kgDM}$ ) were found on some farms in December only. Pastures on all farms were adequate in $\mathrm{Cu}$ (i.e., $>5 \mathrm{mg}$ $\mathrm{Cu} / \mathrm{kgDM}$ ) for sheep but were inadequate (i.e., $<10 \mathrm{mg}$ $\mathrm{Cu} / \mathrm{kgDM}$ ) for cattle in December and on some farms in February and July. The concentration of Mo in the pastures was usually less than $1.0 \mathrm{mg} / \mathrm{kgDM}$ while a few pastures did contain $1.8 \mathrm{mg} \mathrm{Mo/kgDM}$. Pasture I concentrations were low (i.e., $<0.15 \mathrm{mg} \mathrm{I} / \mathrm{kgDM}$ ) on about a third of the farms in February.

With the exception of Se in the leaves of swedes and kale and $\mathrm{I}$ in leaves of swedes and stems of kale, the brassica crops did not meet the dietary trace element requirements of sheep and cattle (Table 2).

On the basis of serum and liver Vitamin $B_{12}$ concentrations, lambs on farms 1, 2, 4, 6, 7 and 9 were found to be deficient in Co (Vitamin $\mathrm{B}_{12}$ ) (Table 3), and
Table 3 Mean blood and liver Vitamin $\mathrm{B}_{12}$, Se and $\mathrm{Cu}$ concentrations in Wendon Valley sheep. Data are from the May 1998 sampling. Bold figures indicate deficiencies.

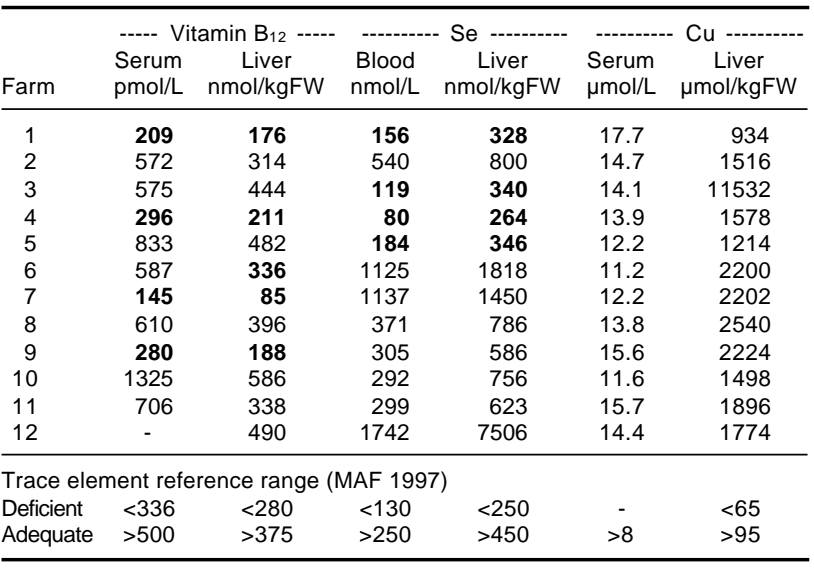

on the basis of blood and liver Se concentrations, lambs on farms 1, 3, 4 and 5 were also shown to be deficient in $\mathrm{Se}$. None of the lambs were $\mathrm{Cu}$-deficient.

None of the cattle were Co deficient but cattle were Se deficient on farms 7, 8 and 11 (Table 4). With the exception of farm 12, all of the cattle had lower serum $\mathrm{Cu}$ concentrations and depleted liver $\mathrm{Cu}$ stores.

None of the deer were Co or Se deficient but liver $\mathrm{Cu}$ stores of deer on both farms were depleted (Table 5).

The treatments increased $(30-60 \%)$ the mean Vitamin $\mathrm{B}_{12}$ tissue concentrations (Table 6) and more than doubled the mean Se concentrations in blood (serum) and liver of all treated lambs when compared to untreated animals at days 120 and 180 as well as their daily liveweight gains to Vitamin $\mathrm{B}_{12}$ on farm $7(\mathrm{P}<0.01)$ and to Se supplementation on farms 5 and $6(\mathrm{P}<0.05)$.

The ewes on farm 3 were fed pasture only while ewes on farm 5 were fed swedes for 8 weeks during 
mid to late lactation. The I supplementation significantly $(\mathrm{P}<0.01)$ increased plasma and milk I concentrations at 210 days after treatment on both farms and prevented goitre in the lambs born to ewes fed the swedes (Table 7). The I status of the ewes on farm 3 was significantly higher $(\mathrm{P}<0.05)$ than those on farm 5 . No goitre was observed in the lambs born to pasturefed ewes on farm 3.

Table 4 Mean Blood and liver Vitamin $\mathrm{B}_{12}$, Se and $\mathrm{Cu}$ concentrations in Wendon Valley cattle. The Vitamin $B_{12}$ and Se data are from the October 1998 sampling and the $\mathrm{Cu}$ is from the April 1998 and October 1998 samplings. Figures in bold indicate deficiencies.

\begin{tabular}{|c|c|c|c|c|c|c|}
\hline \multirow[t]{2}{*}{ Farm } & $\begin{array}{l}\text { Vitamin } B_{12} \\
\text { Serum } \\
(\text { pmol/L) }\end{array}$ & \multicolumn{2}{|c|}{$\begin{array}{cc}\text { Blood } & \text { Le } \\
\mathrm{nmol} / \mathrm{L} & \mathrm{nmol} / \mathrm{kgFW}\end{array}$} & \multicolumn{3}{|c|}{$\begin{array}{lc}\text { Serum } & \text { Liver } \\
\mu \mathrm{mol} / \mathrm{L} & \mu \mathrm{mol} / \mathrm{kgFW}\end{array}$} \\
\hline & Oct & Oct & Oct & April & Oct & Oct \\
\hline 2 & 207 & 610 & 1353 & 9.0 & 6.9 & 75 \\
\hline 6 & 235 & 700 & 1110 & 8.9 & 3.6 & 57 \\
\hline 7 & 214 & 190 & 620 & 10.8 & 3.0 & 28 \\
\hline 8 & 217 & 152 & 418 & 9.3 & 6.7 & 67 \\
\hline 10 & 284 & 893 & 1618 & 9.4 & 6.9 & 66 \\
\hline 11 & 480 & 215 & 500 & 10.0 & 7.8 & 52 \\
\hline 12 & 298 & 281 & 886 & 9.6 & 8.5 & 485 \\
\hline \multicolumn{7}{|c|}{ Trace element reference range (MAF 1997) } \\
\hline Deficie & ent $<73$ & $<130$ & $<600$ & $<4.5$ & $<45$ & \\
\hline Adequ & late - & $>250$ & $>850$ & $>8.0$ & $>95$ & \\
\hline
\end{tabular}

Table 5 Mean blood and liver Vitamin $B_{12}$, Se and $\mathrm{Cu}$ concentrations in Wendon Valley deer. Data are from the October 1998 sampling. Figures in bold indicate deficiencies.

\begin{tabular}{lccccc}
\hline & $\begin{array}{c}\text { Vitamin } B_{12} \\
\text { Serum } \\
\text { Farm }\end{array}$ & $\begin{array}{c}\text { Blood } \\
\text { Bmol/L) }\end{array}$ & $\begin{array}{c}\text { nmol/L } \\
\text { nmol/kgFW }\end{array}$ & $\begin{array}{c}\text { Serum } \\
\mu \mathrm{mol} / \mathrm{L}\end{array}$ & $\begin{array}{c}\text { Liver } \\
\mu \mathrm{mol} / \mathrm{kgFW}\end{array}$ \\
\hline 3 & 117 & 794 & 1278 & 12.3 & $\mathbf{8 1}$ \\
4 & 90 & 203 & 633 & $\mathbf{5 . 2}$ & $\mathbf{8 3}$ \\
\hline Trace elemen reference range (MAF 1997) & & \\
Deficient & - & - & - & $<4$ & $<60$ \\
Adequate & $>73$ & $>120$ & - & $>8$ & $>100$ \\
\hline
\end{tabular}

\section{Discussion}

When the intakes of Vitamin $\mathrm{B}_{12}, \mathrm{Se}, \mathrm{Cu}$ and $\mathrm{I}$ do not meet the animal's requirements the trace element stores become depleted, blood (serum) Vitamin $\mathrm{B}_{12}, \mathrm{Se}, \mathrm{Cu}$ and I concentrations decrease and the animals become deficient. This then leads to a dysfunction of biochemical processes, clinical signs of the deficiency and impaired animal performance (Underwood \& Suttle 1999).

Trace element deficiencies are detected when the performance of supplemented animals is significantly greater than that of untreated animals (Clark et al. 1985). The biochemical criteria or pasture and animal tissue reference ranges used to determine the Co

Table 6 The effect of Vitamin $B_{12}$ and Se supplementation on mean tissue Vitamin $B_{12}$ and Se concentrations and mean ( \pm S E) lamb growth rate on Wendon Valley farms. Figures in bold indicate deficiencies.

\begin{tabular}{|c|c|c|c|c|c|c|c|c|c|c|}
\hline \multirow{2}{*}{\multicolumn{2}{|c|}{$\begin{array}{l}\text { Farm } \\
\text { Treatment }\end{array}$}} & \multicolumn{3}{|c|}{$\begin{array}{l}\text { Serum Vitamin } B_{12} \\
(\mathrm{pmol} / \mathrm{L})\end{array}$} & \multirow[t]{2}{*}{$\begin{array}{l}\text { Liver Vitamin } B_{12} \\
(\mathrm{nmol} / \mathrm{kg} \mathrm{FW})\end{array}$} & \multicolumn{3}{|c|}{$\begin{array}{l}\text { Blood Se } \\
(\mathrm{pmol} / \mathrm{L})\end{array}$} & \multirow[t]{2}{*}{$\begin{array}{c}\text { Liver Se } \\
(\mathrm{nmol} / \mathrm{kg} \mathrm{FW})\end{array}$} & \multirow{2}{*}{$\begin{array}{l}\text { Daily weight gain } \\
\text { (g/day) }\end{array}$} \\
\hline & & Day 1 & 120 & 180 & & Day 1 & 120 & 180 & & \\
\hline 1 & Control & 738 & 1045 & 680 & 330 & 583 & 631 & 787 & 1127 & $127 \pm 4.5$ \\
\hline & VitB $_{12}$ & 608 & 1377 & 1292 & 448 & & & & & $124 \pm 3.7$ \\
\hline & & & & & & 804 & 2083 & 2371 & 2781 & $135 \pm 3.9$ \\
\hline & $\mathrm{itB}_{12}+\mathrm{Se}$ & 651 & 1451 & 1263 & 665 & 695 & 2466 & 3031 & 3421 & $133 \pm 3.5$ \\
\hline 2 & $\begin{array}{r}\text { Control } \\
\text { VitB }_{12}\end{array}$ & $\begin{array}{l}767 \\
777\end{array}$ & $\begin{array}{r}521 \\
1343\end{array}$ & $\begin{array}{r}501 \\
1040\end{array}$ & $\begin{array}{l}267 \\
565\end{array}$ & & & & & $\begin{array}{l}144 \pm 5.1 \\
156 \pm 5.8\end{array}$ \\
\hline 3 & $\begin{array}{r}\text { Control } \\
\text { Se }\end{array}$ & & & & & $\begin{array}{l}311 \\
423\end{array}$ & $\begin{array}{r}134 \\
1759\end{array}$ & $\begin{array}{r}144 \\
1923\end{array}$ & $\begin{array}{r}390 \\
2769\end{array}$ & $\begin{array}{l}97 \pm 3.2 \\
87 \pm 4.0\end{array}$ \\
\hline 4 & $\begin{array}{r}\text { Control } \\
\text { Vit } B_{12}\end{array}$ & $\begin{array}{l}858 \\
891\end{array}$ & $\begin{array}{l}1006 \\
1428\end{array}$ & $\begin{array}{r}983 \\
1450\end{array}$ & $\begin{array}{l}396 \\
584\end{array}$ & 761 & 295 & 140 & 384 & $\begin{array}{l}107 \pm 6.9 \\
114 \pm 5.4\end{array}$ \\
\hline & & & & & & 684 & 2490 & 2863 & 3419 & $117 \pm 5.3$ \\
\hline & $\mathrm{itB}_{12}+\mathrm{Se}$ & 880 & 1181 & 1267 & 558 & 790 & 2837 & 2806 & 3877 & $118 \pm 5.2$ \\
\hline 5 & $\begin{array}{r}\text { Control } \\
\mathrm{Se}\end{array}$ & & & & & $\begin{array}{l}433 \\
473\end{array}$ & $\begin{array}{l}121 \\
808\end{array}$ & $\begin{array}{r}66 \\
933\end{array}$ & $\begin{array}{r}252 \\
1290\end{array}$ & $\begin{array}{c}79 \pm 3.9 \\
93 \pm 4.1^{* a}\end{array}$ \\
\hline 6 & $\begin{array}{r}\text { Control } \\
\mathrm{Se}\end{array}$ & & & & & $\begin{array}{l}354 \\
343\end{array}$ & $\begin{array}{r}116 \\
1644\end{array}$ & $\begin{array}{r}82 \\
1490\end{array}$ & $\begin{array}{r}279 \\
1865\end{array}$ & $\begin{array}{l}145 \pm 3.5 \\
154 \pm 3.3^{\star}\end{array}$ \\
\hline 7 & $\begin{array}{r}\text { Control } \\
\text { VitB }_{12}\end{array}$ & $\begin{array}{l}71 \\
75\end{array}$ & $\begin{array}{l}169 \\
465\end{array}$ & $\begin{array}{l}266 \\
437\end{array}$ & $\begin{array}{r}72 \\
186\end{array}$ & & & & & $\begin{array}{c}82 \pm 6.6 \\
191 \pm 5.4^{\star \star}\end{array}$ \\
\hline 9 & $\begin{array}{r}\text { Control } \\
\text { VitB }_{12}\end{array}$ & $\begin{array}{l}733 \\
608\end{array}$ & $\begin{array}{r}564 \\
1231\end{array}$ & $\begin{array}{r}582 \\
1390\end{array}$ & $\begin{array}{l}283 \\
542\end{array}$ & & & & & $\begin{array}{c}92 \pm 6.4 \\
90 \pm 8.00\end{array}$ \\
\hline & Control & 1269 & 1257 & 1130 & 501 & & & & & $167 \pm 4.4$ \\
\hline & VitB $_{12}$ & 1403 & 1646 & 1364 & 813 & & & & & $177 \pm 4.6$ \\
\hline
\end{tabular}

a Means significantly different ${ }^{*} \mathrm{P}<0.05,{ }^{* *} \mathrm{P}<0.01$ 
Table 7 Effect of an lodine premating injection on ewe mean $( \pm$ $S$ E) plasma and milk I concentrations at docking and new-born lamb thyroid liveweight ratios at post mortem.

\begin{tabular}{llcc}
\hline & & \multicolumn{2}{c}{ Control } \\
\hline Farm & Winter feeding & \multicolumn{2}{c}{ Plasma I $(\mu \mathrm{g} / \mathrm{L})^{\mathrm{a}}$} \\
3 & pasture & $43 \pm 3.0$ & $65 \pm 4.0^{* *}$ \\
5 & pasture/swedes & $29 \pm 3.0$ & $51 \pm 3.5^{* *}$ \\
& & \multicolumn{2}{c}{ Milk I $(\mu \mathrm{g} / \mathrm{L})$} \\
3 & pasture & $72 \pm 14.0$ & $197 \pm 34.0^{* *}$ \\
5 & pasture/swedes & $26 \pm 7.0$ & $132 \pm 15.0^{* *}$
\end{tabular}

Thyroid (g)/Liveweight $(\mathrm{kg})^{\mathrm{b}}$

\begin{tabular}{llll}
3 & pasture & 0.21 & 0.21 \\
5 & pasture/swedes & 2.29 & $0.37^{* *}$ \\
\hline
\end{tabular}

a Significance ** $\mathrm{P}<0.01$

b Thyroid $(\mathrm{g}) /$ /iveweight $(\mathrm{kg})$ greater than 0.4 reflect a subclinical I deficiency (Clark et al. 1998)

(Vitamin $\mathrm{B}_{12}$ ), Se, $\mathrm{Cu}$ and I status of livestock have been established from animal trials where the responses in animal performance or reduced incidence of disease to trace element supplementation were related to changes in pasture, blood (serum) and liver Co, (Vitamin $\mathrm{B}_{12}$ ), $\mathrm{Se}, \mathrm{Cu}$ and I concentrations (MAF 1997).

As the pasture trace element concentrations were different between transects within a farm and between seasons, it is important to collect 3-5 samples per farm in order to represent the farm in terms of differences in soil types, pasture composition and topography. The seasonal nature of trace element deficiencies and animal requirements means that the timing of the collection of pasture samples is very important. For example, Co and Se deficiencies occur in young lambs during spring and early summer (Clark et al. 1985; Metherell et al. 1997) while a high $\mathrm{Cu}$ status in cattle in the autumn is necessary to counter the winter decline in liver $\mathrm{Cu}$ stores and to ensure an adequate $\mathrm{Cu}$ status during the spring mating (West \& Sargison 1998). Likewise the premating Se and I status of ewes in the autumn must be adequate to ensure a good lambing percent (Metherell et al. 1998; Clark et al. 1998). Mixed grass/clover samples of actively growing pasture should therefore be collected during November/December and February/March to assess the trace element concentrations at critical times of sheep, cattle and deer. The impact of the $\mathrm{Cu} \times \mathrm{Mo}$ interaction on $\mathrm{Cu}$ requirements can also be determined from pasture $\mathrm{Cu}$, Mo and $\mathrm{S}$ (Grace 1994).

Brassica crops provide adequate energy and crude protein as a winter forage but they are low in $\mathrm{Co}, \mathrm{Cu}$ and $\mathrm{I}$ as well as containing goitrogens (Grace et al. 2000). Therefore, it is important that the I status of ewes and the $\mathrm{Cu}$ status of cattle is adequate to high in the autumn before feeding brassicas to ensure that goitre does not occur in new-born lambs and that the $\mathrm{Cu}$ status is adequate for the spring mating of cows.

A comparison of the blood and liver Vitamin $\mathrm{B}_{12}$, and Se concentrations of the monitor lambs, on the 12 farms with the reference ranges, showed that six farms were Co deficient ranging from a very deficient property (farm 7) to properties that were marginally Co deficient. A marked response in lamb growth to Vitamin $\mathrm{B}_{12}$ supplementation was observed on farm 7 during 1998/ 1999. As the severity of Co deficiency varies from season to season, the magnitude of lamb growth responses to Vitamin $\mathrm{B}_{12} /$ Co supplementation will also vary (Lee 1951). Four farms, not necessarily the same farms, were marginally Se deficient. These properties also had generally low pasture Co and Se concentrations. All sheep had an adequate $\mathrm{Cu}$ status. The monitor calves showed that the cattle had an adequate Vitamin $\mathrm{B}_{12}$ status while their Se status on three farms out of seven was deficient. On all farms, except one, the liver $\mathrm{Cu}$ stores and bloods $\mathrm{Cu}$ concentrations of the young cattle decreased markedly over the winter/early spring. The reasons for this decline in $\mathrm{Cu}$ status is not known but it could be related to increased soil ingestion and or increases in pasture Mo concentrations (Grace 1994).

The differences observed in the incidence of trace element deficiencies between sheep and cattle on the Wendon Valley farms support the findings that the dietary Co requirements of sheep are about double those of cattle while the dietary $\mathrm{Cu}$ requirements of cattle are about double those of sheep (Grace 1994). The dietary Se requirements of sheep and cattle are similar. In deer, the dietary Co and Se requirements are less or similar to those of sheep while their dietary $\mathrm{Cu}$ requirements appear to be similar to those of cattle.

While soils low in Co and Se result in pastures also being low in Co and Se (Hawke et al.1994), the use of this soil trace element data is usually not sensitive enough to determine the $\mathrm{Co} / \mathrm{Vitamin} \mathrm{B} 12$ and Se status of grazing livestock. This study has clearly demonstrated that using the recommended pasture and animal tissue sampling protocols, and the established pasture and tissue trace element reference ranges, allows the trace element status of grazing livestock to be determined. Further, the observed between-farm variation means that these diagnostic procedures need to be carried out for each farm as part of their overall animal health programme.

\section{ACKNOWLEDGEMENTS}

Ian Baker, Neville and Margaret Bryant, Jack and Gill Cooper, Steve and Judy Dennis, Willie Heenan, Daryl and Ruth McRae, Jack and Louise Meehan, Neil and 
Linda Miller, Neil and Debbie Sutherland, Dougal and Gay Stringer, Dennis and Liz O'Connell, Stuart and Paulette Watson for the use of their facilities and properties. The Agricultural and Marketing Research and Development Trust (AGMARDT) and Ravensdown Co-op Ltd for funding.

\section{REFERENCES}

Andrews, E.D.; Grant, A.B.; Stephenson, B.J. 1963. Weight responses of sheep to cobalt and selenium in relation to Vitamin $\mathrm{B}_{12}$ and selenium concentrations in liver and kidney. New Zealand Journal of Agricultural Research 7: 17-27.

Clark, R.G.; Wright, D.F.; Millar, K.R. 1985. A proposed new approach and protocol to defining mineral deficiencies using reference curves. Cobalt deficiency in young sheep is used as a model. New Zealand Veterinary Journal 33: 1-5.

Clark, R.G.;Sargison, N.D.;West, D.M.; Littlejohn, R.P. 1998. Recent information on iodine deficiency in New Zealand sheep flocks. New Zealand Veterinary Journal 46: 216-222.

Cunningham, I.J. 1950. Copper and molybdenum in relation to diseases of cattle and sheep in New Zealand. pp. 246. In: Symposium in Copper Metabolism. Eds. McElroy, W.D.; Glass, B. The John Hopkins Press, Baltimore.

Hawke, M.F.; O'Connor, M.B.; Johnston, T.J.M.; Waller, J.E.; Addison, B. 1994. Monitoring cobalt status - experiences in the central North Island. Proceedings of the New Zealand Grassland Association 56: 249-254.

Hewitt, A.E. 1992. New Zealand Soil Classification, DSIR Land Resources Scientific Report No.19 DSIR Land Resources, Lower Hutt.
Grace, N.D. 1992. Prevention of trace element deficiencies in grazing ruminants: an evaluation of methods. Proceedings of the New Zealand Grassland Association 54: 31-34.

Grace, N.D. 1994. Managing trace element deficiencies. New Zealand Pastoral Agricultural Institute Ltd, Palmerston North.

Grace, N.D.; Craighead, M.; Watt B. 2000. The macroand microelement content of swedes and kale and the effect of the use of trace element amended fertilisers on $\mathrm{Co}$, Se and $\mathrm{Cu}$ concentrations. New Zealand Journal of Agricultural Research (accepted).

Lee, J.H. 1951. Cobalt and copper deficiencies affecting sheep in South Australia. Part 1. Symptoms and distribution. Journal of Agriculture Science, South Australia 54: 475-490.

Metherell, A.K.; Owens, J.L.; Moore, C.H.; MacIntosh, C.G. 1997. Selenium supplementation alternatives for the South Island high country. Proceedings of the New Zealand Grassland Association 58: 199204.

MAF. 1997. Optigrow trace monitoring manual. MAF Quality Management

Sinclair, D.P.; Andrews, E.D. 1958. Prevention of goitre in newborn lambs from kale fed ewes. New Zealand Veterinary Journal 6: 87-95.

West, D.M.; Sargison, N.D. 1998. Copper supplementation of grazing cattle using pasture topdressing and individual animal treatment. Proceedings of the New Zealand Grassland Association 60: 229232.

Underwood, E.J.; Suttle, N.F. 1999. The mineral nutrition of livestock. 3rd edition. CABI Publishing, Wallingford, U.K. 